\title{
Introduction: \\ The Fiction of History and the History of Fiction
}

\author{
Rodica Grigore ${ }^{1}$
}

[Article copies available for a fee from The Transformative Studies Institute. E-mail address: journal@transformativestudies.org Website: http://www.transformativestudies.org (C2021 by The Transformative Studies Institute. All rights reserved.]

"Everything that is not literature is life, especially history," according to one of the characters in History of the Siege of Lisbon, the well-known novel authored by José Saramago. The Portuguese writer often insisted upon the supremacy of fiction over all the other fields that use words in order to express (or validate) human existence. Thus, even history turns out to be a creative transformation of the contingent world, proving that the entirety of reality is just a matter of perspective and that in the contemporary world there is no such thing as an ultimate truth.

Nevertheless, sometimes people tend to trust historic discourse too much, generally considering it an expression of some kind of scientific research, whereas they tend to trust literature too little, regarding it primarily as fiction, a mere invention, or the simple expression of the writer's imagination. And yet, once written, history (any history!) becomes, in a more or less obvious way, another fiction: after all, any objective fact is transformed by the historian's inherent subjectivity and altered through the process of selection (i.e. only the most significant events are thoroughly recorded, in order to enrich the final text - be it a historical document or not - with a logical organizing pattern). All these underline the fragmented character of any history or historical discourse, and also the way it follows and obeys the aesthetic norms of a written text, in other words, those of fiction.

History and fiction prove therefore to be some of the most important elements found - both thematically and symbolically - in world literature. And the re-evaluation of the relationship between the two

\footnotetext{
${ }^{1}$ Rodica Grigore, Ph.D., guest co-editor of this special issue of Theory in Action, along with Jay Corwin Address correspondence to: Rodica Grigore, e-mail: rodica.grigore@gmail.com.
} 